\title{
Güneydoğu Anadolu Bölgesinde Antep Fıstığı Yetiştirilen Bazı Alanların Topraklarında Borun (B) Kimyasal Fraksiyonları ve Toprak Özellikleri İle İlişkisi
}

\author{
Kadir SALTALI ${ }^{1}$, Esra GÜNEŞ², Bedriye BILİं ${ }^{3}$ \\ Kahramanmaraş Sütçü İmam Üniversitesi, Ziraat Fak, Toprak Bilimi ve Bitki Besleme Bölümü. Kahramanmaraş \\ ${ }^{1}$ https://orcid.org/0000-0001-5301-1350, ${ }^{2}$ https://orcid.org/0000-0002-0711-5527, ${ }^{3}$ https://orcid.org/0000-0002-0038-9509 \\ $\triangle$ : kadirs@ksu.edu.tr
}

\begin{abstract}
ÖZET
Bor bitkiler için gerekli mikro bitki besin elementlerinden birisidir. Topraklarda borun hangi toprak bileşenleri ile ilişkili olduğunun belirlenmesi, bor dinamiği ve bitkiler tarafından alınabilirliği hakkında değerlendirmeler yapmamıza yardımcı olmaktadır. Bu çalışmada, Güney Doğu Anadolu Bölgesi'nde bulunan Gaziantep ilinin 15 farklı alanından 0-30 $\mathrm{cm}$ toprak derinliğinden alınan toprak örneklerinde, borun; kolay çözünebilir (KÇ-B), spesifik olarak adsorbe olmuş (SPA-B), oksitlere bağlı (OK-B), organik maddeye bağlı (OM-B) ve bakiye (RES-B) fraksiyonları belirlenmiş ve bu fraksiyonların bazı toprak özellikleri ile ilişkileri incelenmiştir. Topraklarda toplam bor (TOP-B) içeriğinin fraksiyonlardaki ortalama dağılımının; KÇ-B \% 0.96, SPA-B \% 1.47, OK-B \% 0.84, OM-B \% 0.84 ve RES-B \% 95.88 olduğu belirlenmiştir. Araştırma sonuçlarına göre, toprak organik maddesi ile KÇ-B $(p<0.01)$ ve OM-B $(p<0.05)$ arasında istatistiksel olarak önemli pozitif ilişki elde edilmiştir. Benzer şekilde, KÇ-B ile OK-B arasında da pozitif ( $\mathrm{p}<0.01)$ bir ilişki vardır. Bu sonuçlara göre, organik maddenin topraklarda KÇ-B içeriğini olumlu yönde etkilediği şeklinde yorumlanabilir
\end{abstract}

Araştırma Makalesi
$\begin{array}{ll}\text { Makale Tarihçesi } \\ \text { Geliş Tarihi } \quad: 29.04 .2020 \\ \text { Kabul Tarihi } \quad: 18.06 .2020\end{array}$

Anahtar Kelimeler
Antepfistığı
Bor fraksiyonları
Siralı ekstraksiyon
Toprak

Boron (B) Chemical Fractions and Its Relationships with Soil Properties in the Some Areas of Pistachios Grown in the South East Anatolia Region

\section{ABSTRACT}

Boron (B) is one of the essential nutrients required for plants. Determining of the relation between $\mathrm{B}$ fractions and soil components is useful tool to make assessments about the B dynamics in the soil and plant uptake. In this study, soil samples were taken from 0-30 cm soil depths from 15 different locations of Gaziantep in South East Anatolia Region to determine chemical fractions of $\mathrm{B}$ such as readily soluble B (KÇ-B), specifically adsorbed B (SPA-B), oxide bound B (OK$\mathrm{B}$ ), organically bound B (OM-B) and residual B (RES-B), and their relation to the soil properties. The average contribution of chemically defined fractions to total B were determined as KÇ-B 0.96\%, SPA-B $1.47 \%$, OK-B $0.84 \%$, OM-B $0.84 \%$, and RES-B $95.88 \%$, respectively. Moreover, the relationship between soil B fractions and some soil characteristics has also been examined. The results of the study indicated that three was a positive significant correlations between soil organic matter contents and KÇ-B $(p<0.01)$ and OM-B $(p<0.05)$. Similarly, there was a positive $(\mathrm{p}<0.01)$ relationship between KÇ-B and OK-B. This could be interpreted that organic matter can be a key soil properties to increase the amount of KÇ-B in the studied soils.

\section{Research Article}

$\begin{array}{ll}\text { Article History } & \\ \text { Received } & : 29.04 .2020 \\ \text { Accepted } & : 18.06 .2020\end{array}$

Keywords

Pistachios

Boron fractions

Sequential extraction

Soil.

To Cite : Saltalı K, Güneş E, Bilir B 2020. Güneydoğu Anadolu Bölgesinde Antep Fıstığı Yetiştirilen Bazı Alanların Topraklarında Borun (B) Kimyasal Fraksiyonları ve Toprak Özellikleri ile İlişkisi. KSÜ Tarım ve Doğa Derg 23 (6): 1656-1662. DOI: 10.18016/ksutarimdoga.vi.728795.

\section{GİRIŞ}

Güneydoğu Anadolu Bölgesi Antep fistığının gen merkezlerinden birisidir. Bölgenin tarımsal üretiminde Antep fıstığı önemli bir yer almaktadır. 
Ekonomik olarak önemli olan bu bitkinin döllenme biyolojisi, verim ve kalite üzerinde etkili olan besin maddelerinden birisi de bor elementidir. Bor noksanlığı Antep fistığında döllenme yetersizliğine, erken çiçek ve meyve dökümüne neden olmaktadır (Açar ve ark., 2016). Aynı zamanda bor bitkilerin büyüme ve gelişmelerini düzenleyen, fizyolojik olaylarda etkili bir mikro besin elementidir. Bor bitkilerde hücre duvarının oluşması, polen çimlenmesi, polen tüpü büyümesi, karbonhidrat ve protein sentezi gibi birçok fonksiyonu vardır. Bor noksanlığında bitkilerde kloroz ve nekrozlar, yaprak, gövde ve meyvede çatlama, mantarlaşma, rozetleşme tomurcuk ve çiçek oluşumunda azalma gibi birçok belirtiler oluşabilmektedir (Güneş ve ark., 2000 ). Hem noksanlığı hem de toksitesi yönüyle bitkisel üretimde sorun olan borun, tarım topraklarındaki fazlalığı veya noksanlığı bitkilerde beslenme bozukluklarının ortaya çıkmasına, verim ve kalitenin azalmasına neden olmaktadır (Degryse, 2017).

Bitkiler boru pH'ya bağlı olarak borik asit $\left(\mathrm{H}_{3} \mathrm{BO}_{3}\right)$ veya borat anyonları $\mathrm{B}(\mathrm{OH})_{4}^{-}$formunda alırlar. Bor adsorpsiyonu $\mathrm{pH}$ değeri 7.0'den küçük olan topraklarda çok az olurken, $\mathrm{pH}$ değeri 7.0-9.0 aralığında hızla artmaktadır (Degryse, 2017). Gaziantep yöresi topraklarının $\mathrm{pH}$ değeri 7.01-8.40 arasında (ortalama 7.74), kireç içeriği ise \% 0.10-63.0 arasında (ortalama 7.87) değişmektedir (Karaduman ve Çimrin, 2016). Bölgede Antep fistığı genellikle yüksek pH ve kireçli topraklarda yetiştirilmektedir. Yüksek kireç ve pH'ya sahip topraklarda bor adsorpsiyonu yüksektir (Baydaa ve ark., 2019). Ayrıca, bor adsorpsiyonunda toprakların kil içeriği, organik madde kapsamı, oksihidratlar ve toprak tekstürü de etkilidir (Elrashidi ve O'Connor, 1982, Padbhushan ve Kumar 2017). Bitkilerin bor ile beslenmesinde toprak bileşenleri ve toprak özellikleri, borun kimyasal fraksiyonlardaki dağılımını önemli düzeyde etkilemektedir (Saltalı ve Akın, 2010).

Topraklarm bor fraksiyonu ve bu fraksiyonların toprak özellikleri ve zeytin bitkisinin bor alımı arasındaki ilişkilerin araştırıldığı bir çalışmada, toplam bor içeriğinin; \%85-88'ni bakiye bor, \%2.844.50'ni organik bileşiklere bağlı bor, \%0.93-1.31'ni spesifik adsorbe bor, \%7.27-8.31'ni oksit bileşiklerine bağlı bor ve \%0.40-0.50'ni ise kolay çözünebilir bor (alınabilir) fraksiyonları oluşturmaktadır. Aynı çalışmada bor fraksiyonları ile meyve bor konsantrasyonu arasında yakın ilişkilerin olduğu rapor edilmiştir (Gürel ve ark., 2019).

Tokat Kazova topraklarda bor fraksiyonlarının araştırıldığı bir çalışmada, toplam bor içeriğinin; \% 12.6’ni kolay çözünebilir bor, \% 5.1'ni spesifik adsorbe bor, \% 11.8'ni oksitlere bağlı bor, \% 3.2'ni organik bileşiklere bağlı bor, \%67.3'nü residüyal borun oluşturduğu ve toprak özellikleri ile bor fraksiyonları arasındaki önemli istatistiksel ilişkilerin olduğu bildirilmiştir (Saltalı ve Akın, 2010).

Borun kimyasal olarak fraksiyonlarına ayrılması ve bu fraksiyonların toprak özellikleri ile ilişkilerinin saptanması topraklarda borun davranışı, bitkiler tarafından alınabilirliği ve topraklarda bağlanma formları hakkında bilgiler vermektedir. Farklı toprak bileşenlerindeki bu dağılımın bilinmesi, borun topraklardaki kimyasını ve bu fraksiyonların bitki alımına potansiyel katkısını anlamak açısından bir temel oluşturur (Datta ve ark., 2002, Padbhushan ve Kumar, 2017).

$\mathrm{Bu}$ nedenle, Antep fistığ topraklarında borun toprakta hangi fraksiyonlarda bulunduğunun araştırılması ve toprak özellikleri ile arasındaki ilişkilerin belirlenmesi önem arz etmektedir.

Bu çalışmanın amacı, Güneydoğu Anadolu Bölgesi'nde bulunan Gaziantep ilinde Antep fistığ 1 yetiştirilen alanlardan alınan topraklarda borun kimyasal fraksiyonlarını belirlemek ve bu fraksiyonların (çözünebilir bor, spesifik olarak adsorbe olmuş bor, oksitlere bağlı bor, organik bileşiklere bağlı bor ve residüyal bor) bazı toprak özellikleri ile arasındaki ilişkileri belirlemektir.

\section{MATERYAL ve METOT}

\section{Materyal}

Araştırma alanı Güney Doğu Anadolu Bölgesi'nde bulunan Gaziantep ilini kapsamaktadır. Bu çalışmada, Gaziantep ilinin farklı ilçelerinden (Yavuzeli, Şehitkamil, Nizip, Karkamıs) 15 farklı noktadan $\quad$ 0-30 $\mathrm{cm}$ derinlikten alınan topraklar materyal olarak kullanılmıştır (Şekil 1). Alınan toprak örnekleri kurutulduktan sonra, $2 \mathrm{~mm}$ ' lik elekten elenerek analize hazır hale getirilmiştir.

\section{Metotlar}

Bünye, Bouyoucus; (1951), hidrometre metoduna göre; suya doygunluk (\%), Richards (1954) tarafindan önerilen metoda göre; $\mathrm{pH}$, saturasyon çamurunda cam elektrotlu $\mathrm{pH}$ metre ile; $\mathrm{EC}\left(\mathrm{dSm}^{-1}\right)$, saturasyon çamurundan EC metre cihazı ile; kireç eşdeğeri $\left(\mathrm{CaCO}_{3}\right)(\%)$, Scheibler kalsimetresinde (Hizalan ve Ünal,1966), organik madde (\%), modifiye edilmiş Walkley-Black yöntemine göre (Nelson ve Sommers, 1996); alınabilir fosfor; Olsen yöntemine göre (Olsen ve ark.,1954); ekstrakte edilebilir potasyum, kalsiyum, magnezyum ve sodyum ( $\left.\mathrm{mg} \mathrm{kg}^{-1}\right)$ amonyum asetat yöntemine göre (Helmke ve Sparks, 1996); yarayışlı mikro elementler ( $\mathrm{Fe}, \mathrm{Zn}, \mathrm{Cu}$ ve $\mathrm{Mn}$ ), Lindsay ve Norvell (1978) tarafindan önerilen metoda göre belirlenmiştir.

Borun Kimyasal Fraksiyonlarına Ayrılması ve Siralı Ekstraksiyonu

Borun sıralı ekstraksiyonu ve analizleri için $5 \mathrm{~g}$ toprak 
alındı ve ardışık olarak aynı örnekte kolay çözünebilir bor $0,01 \mathrm{M} \mathrm{CaCl}_{2}$ çözeltisi ile, spesifik olarak adsorbe olmuş bor $0,05 \mathrm{M} \mathrm{KH}_{2} \mathrm{PO}_{4}$ çözeltisi ile, oksitlere bağlı bor 0,2 $\mathrm{M}$ asidik $\mathrm{NH}_{4}$-oksalat çözeltisi ile, organik bileşiklere bağlı bor $0,02 \mathrm{M} \mathrm{HNO}_{3}$ ve $5 \mathrm{ml} \% 30$ 'luk $\mathrm{H}_{2} \mathrm{O}_{2}$ çözeltisi ile eksrakte edildi ve ICP-OES (Perkin Elmer Optima 4300) cihazında okundu (Hou ve ark., 1994). Toplam bor ise mikrodalga numune hazırlama setinde $\mathrm{HNO}_{3}+\mathrm{HCI}+\mathrm{HF}$ (8:5:1 oranında) yakılarak
Whatman 42 filtre kağıdında süzüldü ve ICP-OES (Perkin Elmer Optima 4300) cihazında okundu (Tessier ve ark., 1979; Datta ve ark., 2002; Hou ve ark. 1996). Bakiye bor fraksiyonun belirlenmesi ise kolay çözünebilir bor, spesifik olarak adsorbe olmuş bor, oksitlere bağlı bor, organik bileşiklere bağlı bor değerleri, toplam bor değerinden çıkarılarak bulunmuştur (Hou ve ark., 1996).

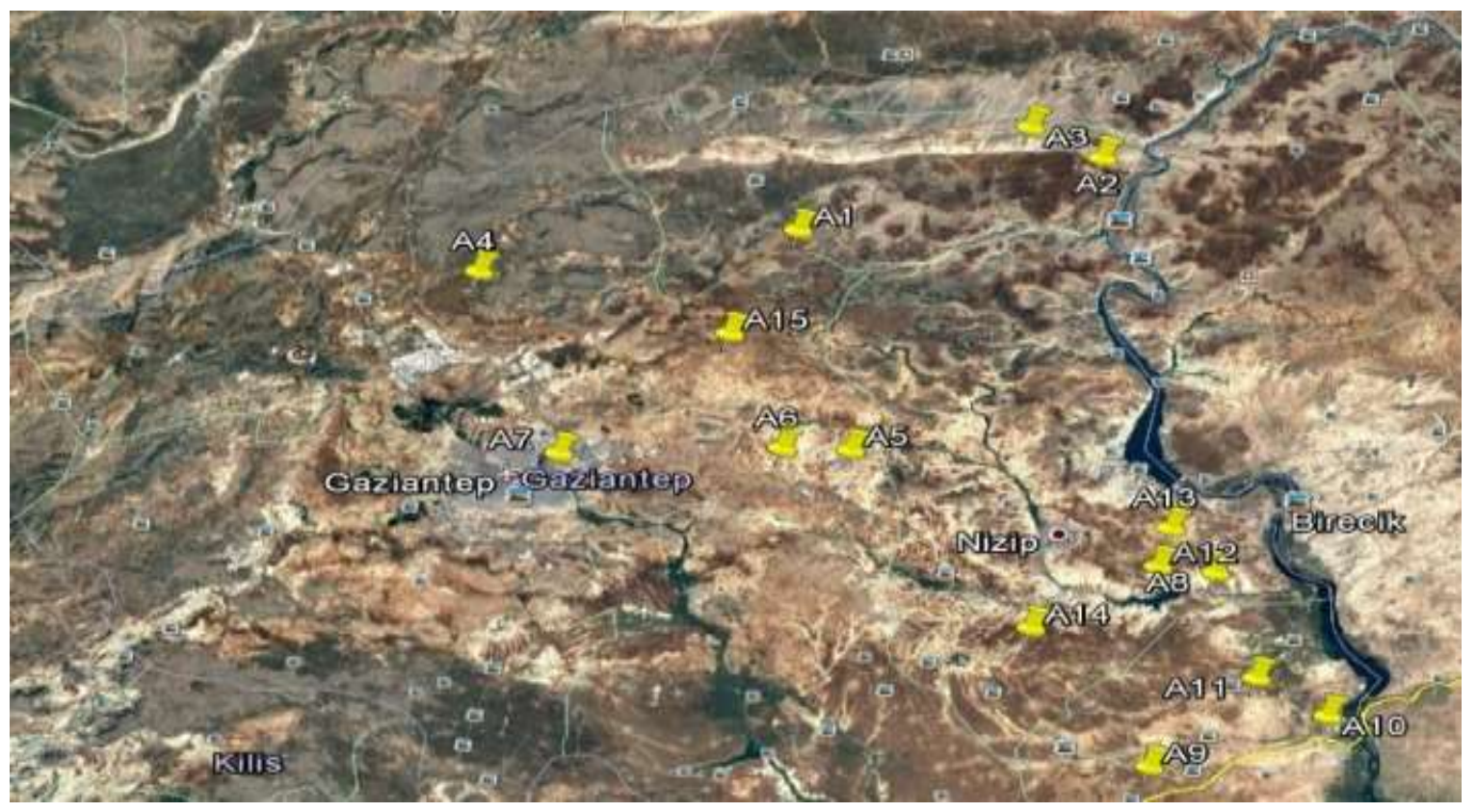

Şekil 1. Toprak örneklerinin alındı ğ yerler

Figure 1. Location of soil samples

\section{İstatistik Analizler}

Toprak özellikleri ve bor fraksiyonları arasındaki ilişkilerin değerlendirilmesinde SPSS 13.0 paket programı kullanılmıştır (SPSS, 2013). Özellikler arasında korelasyon analizi yapılmış olup Pearson korelasyon katsayısı dikkate alınmıştır.

\section{BULGULAR ve TARTIŞMA}

\section{Toprakların Genel Özellikleri}

Araştırma alanından alınan topraklarının bazı fiziksel ve kimyasal özelliklerine ait maksimum, minimum ve ortalama değerleri Çizelge 1'de verilmiştir.

Analiz edilen toprakların pH'sı 6.9-8.0, EC değeri 0.44-1.11 dSm${ }^{-1}$, kireç içerikleri, \% 18.2 - 49.7 arasında değişmektedir. Toprakların organik madde içerikleri \% 0.3-3.1 arasında değişim göstermektedir. Toprakların değişebilir Ca içerikleri 5786-25249 mg $\mathrm{kg}^{-1}, \mathrm{Mg}$ içerikleri $58-762 \mathrm{mg} \mathrm{kg}^{-1}, \mathrm{~K}$ içerikleri $285-822$ $\mathrm{mg} \mathrm{kg}-1$, Na içerikleri ise 245-315 mg kg-1 arasında değiştiği belirlenmiştir. Toprakların alınabilir (DTPA ile ekstrakte edilebilir) Fe içerikleri $1.0-5.68 \mathrm{mg} \mathrm{kg}^{-1}$, Zn içerikleri $0.11^{-0} 0.78 \mathrm{mg} \mathrm{kg}^{-1}$, Cu içerikleri 0.94-2.17 $\mathrm{mg} \mathrm{kg}{ }^{-1}, \mathrm{Mn}$ içerikleri ise 2.05-20.13 $\mathrm{mg} \mathrm{kg}^{-1}$ arasında bulunmuştur.
Toprakların ortalama $\mathrm{pH}$ değeri 7.7 hafif alkalin sinıfta yer almaktadır (Alpaslan ve ark., 1998). Araştırılan toprakların ortalama EC değeri $0.71 \mathrm{dSm}$ 1 olup tuzsuz sinıfindadır (Richard, 1954). Ortalama kireç içeriği \%42.9 olup çok fazla kireçli sınıfındadır (Hızalan ve Ünal, 1966). Ortalama organik madde içeriği \% 1.51 olup az sınıfındadır (Güçdemir, 2006). Alpaslan ve ark., (1998) tarafından bildirildiğine göre toprakların ortalama alınabilir besin elementleri değerlendirildiğinde, fosfor içeriği yeterli, kalsiyum içeriği çok fazla, magnezyum içeriği genellikle yeterli, potasyum içeriği fazla, demir ve çinko içeriği genellikle az, bakır içeriği ise yeterlidir.

Toprakların Bor Fraksiyonları ve Toprak Özellikleri ile İlişkisi

Toprakların bor fraksiyonları Cizelge 2'de ve bu fraksiyonların toprak özellikleri ile arasındaki ilişkiler Çizelge 3’de verilmiştir.

\section{Kolay Çözünebilir Bor (KÇ-B)}

Bu çalışmada, kolay çözünebilir bor $0.17-0.58 \mathrm{mg} \mathrm{kg}{ }^{-1}$ arasında değişmekte olup ortalama kolay çözünebilir B içeriği $0.26 \mathrm{mg} \mathrm{kg}^{-1}$ dır (Çizelge 2). Bu fraksiyonun büyük bir kısmı toprak çözeltisinde bulunmakla 
birlikte bir kısmı da toprak parçacıkları tarafından zayıf bağlarla tutulmaktadır. Aynı zamanda bu fraksiyon, bitkiler tarafindan kolaylıkla yararlanılan fraksiyon olarak değerlendirilmektedir (Hou ve ark., 1994). Kolay çözünebilir bor, toplam borun ortalama $\% 0.96$ 'sını oluşturmaktadır. Harmankaya ve Gezgin (2005), Konya Ovası topraklarında, kolay çözünebilir $\mathrm{B}$ için eksktrakt çözeltisi olarak $0.01 \mathrm{M} \quad \mathrm{CaCI}_{2}$ kullanmışlar. Konya Ovasında kolay çözünebilir B'un 0.0-31.33 mg kg-1 arasında değiştiğini ve ortalama
$3.30 \mathrm{mg} \mathrm{kg}{ }^{-1}$ olduğunu rapor etmişlerdir. Benzer şekilde, Saltalı ve Akın (2010) Tokat yöresi topraklarında yaptıkları çalışmada, kolay çözünebilir bor fraksiyonun $0.23-9.88 \mathrm{mg} \mathrm{kg}^{-1}$ arasinda değiştiğini, ortalamanın $2.11 \mathrm{mg} \mathrm{kg} \mathrm{kg}^{-1}$ olduğunu bildirmişlerdir. Toprakların kolay çözünebilir B içeriklerinin farklı olması ekolojik koşullar ve toprak özellikleri ile ilgili olabilir (Padbhushan ve Kumar, 2017).

Cizelge 1. Toprakların bazı fiziksel ve kimyasal özellikleri

Table 1. Some physical and chemical properties of soils

\begin{tabular}{|c|c|c|c|c|c|c|c|c|c|c|c|c|c|c|c|c|}
\hline $\begin{array}{l}\text { Örn. } \\
\text { No }\end{array}$ & $\mathrm{pH}$ & $\begin{array}{l}\mathrm{EC} \\
\mathrm{d} / \mathrm{m}\end{array}$ & $\begin{array}{l}\mathrm{CaCO}_{3} \\
\ldots\end{array}$ & $\mathrm{OM}$ & $\begin{array}{l}\text { Kum } \\
(\%)\end{array}$ & $\begin{array}{l}\text { Kil } \\
\ldots\end{array}$ & $\begin{array}{l}\text { Silt } \\
\ldots\end{array}$ & $\mathrm{P}$ & $\mathrm{Ca}$ & $\mathrm{Mg}$ & $\begin{array}{c}\mathrm{K} \\
\mathrm{mg} \mathrm{kg}^{-1}\end{array}$ & $\mathrm{Na}$ & $\mathrm{Fe}$ & $\mathrm{Zn}$ & $\mathrm{Cu}$ & $\mathrm{Mn}$ \\
\hline 1 & 7.9 & 0.80 & 41 & 0.3 & 33 & 37 & 30 & 5.4 & 10650 & 416 & 463 & 265 & 1.01 & 0.11 & 0.94 & 2.05 \\
\hline 2 & 7.8 & 0.54 & 50 & 0.4 & 45 & 25 & 30 & 23.5 & 5786 & 58 & 693 & 245 & 1.12 & 0.37 & 0.95 & 3.51 \\
\hline 3 & 7.6 & 0.95 & 44 & 0.6 & 29 & 45 & 26 & 6.6 & 9084 & 512 & 822 & 255 & 1.20 & 0.17 & 1.69 & 3.46 \\
\hline 4 & 7.9 & 0.67 & 50 & 1.2 & 35 & 35 & 31 & 24.3 & 7583 & 266 & 608 & 260 & 1.63 & 0.32 & 1.45 & 5.09 \\
\hline 5 & 7.4 & 0.57 & 49 & 1.6 & 43 & 35 & 22 & 19.8 & 7971 & 77 & 315 & 280 & 2.38 & 0.25 & 1.84 & 6.84 \\
\hline 6 & 6.9 & 0.75 & 49 & 2.2 & 47 & 35 & 18 & 21.0 & 13426 & 243 & 550 & 275 & 2.43 & 0.43 & 1.91 & 8.76 \\
\hline 7 & 7.7 & 0.88 & 38 & 1.1 & 30 & 45 & 25 & 8.6 & 14748 & 634 & 605 & 300 & 3.86 & 0.23 & 1.58 & 5.91 \\
\hline 8 & 7.6 & 0.66 & 49 & 1.8 & 50 & 35 & 15 & 24.2 & 8502 & 153 & 300 & 275 & 4.06 & 0.76 & 1.78 & 15.52 \\
\hline 9 & 7.8 & 0.44 & 49 & 2.1 & 52 & 36 & 12 & 23.7 & 7835 & 88 & 285 & 260 & 3.02 & 0.52 & 1.09 & 10.96 \\
\hline 10 & 7.7 & 0.79 & 49 & 3.1 & 40 & 37 & 23 & 20.7 & 9455 & 200 & 530 & 270 & 4.80 & 0.78 & 2.17 & 18.59 \\
\hline 11 & 7.7 & 0.47 & 21 & 1.7 & 48 & 36 & 16 & 37.0 & 7586 & 88 & 350 & 260 & 4.06 & 0.77 & 1.72 & 20.13 \\
\hline 12 & 7.8 & 1.11 & 18 & 2.1 & 18 & 47 & 34 & 26.0 & 13405 & 627 & 550 & 255 & 5.46 & 0.38 & 1.58 & 4.97 \\
\hline 13 & 7.9 & 0.89 & 49 & 1.5 & 41 & 34 & 25 & 17.4 & 7674 & 83 & 335 & 305 & 5.68 & 0.54 & 1.25 & 9.61 \\
\hline 14 & 8.0 & 0.51 & 38 & 1.3 & 33 & 42 & 25 & 14.0 & 25249 & 762 & 565 & 315 & 4.96 & 0.37 & 1.78 & 9.56 \\
\hline 15 & 7.8 & 0.62 & 49 & 1.6 & 45 & 32 & 23 & 10.4 & 7541 & 91 & 355 & 300 & 2.35 & 0.35 & 1.44 & 3.81 \\
\hline Min. & 6.9 & 0.44 & 18 & 0.3 & 18 & 25 & 12 & 5.4 & 5786 & 58 & 285 & 245 & 1.01 & 0.11 & 0.94 & 2.05 \\
\hline Mak. & 8.0 & 1.11 & 50 & 3.1 & 52 & 47 & 34 & 37.0 & 25249 & 762 & 822 & 315 & 5.68 & 0.78 & 2.17 & 20.13 \\
\hline Ort. & 7.7 & 0.71 & 43 & 1.51 & 39 & 37 & 24 & 18.8 & 10433 & 287 & 488 & 275 & 3.20 & 0.42 & 1.54 & 8.58 \\
\hline
\end{tabular}

Çizelge 2. Topraklarda borun kimyasal fraksiyonları (mgkg-1)

Table 2. Boron chemical fractions in soils (mgkg-1)

\begin{tabular}{lllllll}
\hline Örnek No & KÇ-B $\ldots \ldots$ & SP-B $\ldots \ldots$ & OK-B $\ldots \ldots$ & OM-B & RES-B $\ldots \ldots$ & TOP-B.. \\
\hline 1 & 0.17 & 0.27 & 0.21 & 0.14 & 23.51 & 24.30 \\
2 & 0.18 & 0.34 & 0.19 & 0.13 & 25.46 & 26.30 \\
3 & 0.19 & 0.39 & 0.20 & 0.15 & 30.53 & 31.46 \\
4 & 0.17 & 0.29 & 0.20 & 0.13 & 26.68 & 27.47 \\
5 & 0.25 & 0.42 & 0.16 & 0.22 & 28.75 & 29.80 \\
6 & 0.24 & 0.44 & 0.19 & 0.20 & 45.21 & 46.28 \\
7 & 0.18 & 0.35 & 0.15 & 0.17 & 26.12 & 26.97 \\
8 & 0.28 & 0.50 & 0.23 & 0.26 & 23.87 & 25.14 \\
9 & 0.28 & 0.52 & 0.26 & 0.28 & 23.80 & 25.14 \\
10 & 0.58 & 0.15 & 0.43 & 0.33 & 20.32 & 22.81 \\
11 & 0.32 & 0.52 & 0.24 & 0.29 & 21.77 & 23.14 \\
12 & 0.17 & 0.30 & 0.31 & 0.13 & 22.73 & 23.64 \\
13 & 0.32 & 0.53 & 0.23 & 0.34 & 28.21 & 29.63 \\
14 & 0.27 & 0.54 & 0.21 & 0.33 & 19.46 & 20.81 \\
15 & 0.30 & 0.42 & 0.23 & 0.34 & 23.85 & 25.14 \\
\hline Min. & 0.17 & 0.15 & 0.15 & 0.13 & 19.46 & 20.81 \\
Mak. & 0.58 & 0.54 & 0.43 & 0.34 & 45.21 & 46.28 \\
Ort. & 0.26 & 0.40 & 0.23 & 0.23 & 26.08 & 27.20 \\
\hline
\end{tabular}

KÇ-B, kolay çözünebilir bor; SP-B, spesifik adsorbe bor; OK-B, oksitlere bağlı bor; OM-B, organik maddeye bağlı bor; RES-B, bakiye bor; TOP-B, toplam bor. 
Çizelge 3. Toprakların bor fraksiyonları ile toprak özellikleri arasındaki ilişkiler

Table 3. Relationships between boron fractions of soil and soil properties

\begin{tabular}{lllllllllllll} 
& $\mathrm{pH}$ & $\mathrm{EC}$ & Kireç & $\mathrm{OM}$ & Kum & Kil & Silt & KÇ-B & SP-B & OK-B & OM-B & RES-B \\
\cline { 2 - 12 } KÇ-B & -0.20 & -0.16 & 0.17 & $0.73^{* *}$ & 0.37 & -0.16 & -0.41 & & & & & \\
SP-B & -0.07 & -0.45 & -0.02 & -0.04 & 0.46 & 0.09 & $-0.60^{*}$ & -0.11 & & & & \\
OK-B & 0.18 & 0.19 & -0.16 & $0.70^{* *}$ & -0.05 & 0.10 & -0.03 & $0.76^{* *}$ & -0.42 & & & \\
OM-B & 0.13 & -0.38 & 0.15 & $0.53^{*}$ & -0.48 & -0.18 & $-0.56^{*}$ & $0.76^{* *}$ & 0.46 & 0.37 & & \\
RES-B & $-0.8^{* *}$ & 0.19 & 0.34 & 0.003 & 0.16 & -0.10 & -0.14 & -0.27 & 0.12 & -0.42 & -0.29 & \\
TOP-B & $-0.8^{* *}$ & 0.18 & 0.35 & 0.06 & 0.19 & -0.12 & -0.17 & -0.20 & 0.11 & -0.37 & -0.24 & $0.99^{* *}$ \\
\hline
\end{tabular}

$* * \mathrm{p}<0.01,{ }^{*} \mathrm{p}<0.05$

Araştırmada, en yüksek KÇ-B içeren örneğin aynı zamanda en yüksek organik madde (\% 3.1) içerdiği görülmektedir. Topraklarda kolay çözünebilir bor ile organik madde arasında istatistiksel olarak önemli $(\mathrm{p}<0.01)$ pozitif korelasyon elde edilmiştir (Çizelge 3 ). $\mathrm{Bu}$ durum, topraklarda kolay çözünebilir bor fraksiyonunu organik maddenin olumlu yönde etkilediğini ve kontrol ettiğini göstermektedir. Elrashidi ve O'Connor, (1982), topraklarm alınabilir B içeriği ile organik karbon içeriği arasında önemli pozitif ilişki olduğunu, bu nedenle bitkilerin B ile beslenmesinde organik maddenin önemli olduğunu ileri sürmüştür. Bu durum özellikle alkali topraklarda daha belirgindir. Zira anyonik formda bulunan B formları ile humat/fulvat anyonları ya da bazı organik asitler adsorpsiyon yüzeyleri için rekabet edebilmektedir.

\section{Spesifik Olarak Adsorbe Bor (SP-B)}

Çalışmada, topraklar tarafından spesifik olarak adsorbe edilen bor içeriği 0.15 ile $0.54 \mathrm{mg} \mathrm{kg}^{-1}$ arasında değişmekte olup, ortalama $0.40 \mathrm{mg} \mathrm{kg}^{-1}$ 'dır (Çizelge 2). Spesifik olarak adsorbe edilen B (SP-B), organik/inorganik partiküllerinin ve kil minerallerinin yüzeylerine ve oksitlere bağlanan boru temsil ettiği rapor edilmiştir (Keren ve Gast, 1983). Teknik ve tanımsal olarak spesifik adsorpsiyon, iyonların bağ değişimi ya da oksit yapıları içerisine sızması olarak tanımlanmaktadır (Bayraklı, 1998). Spesifik olarak adsorbe edilen bor içeriği toprakların toplam bor içeriğinin ortalama \% 1.47 ' sini oluşturmaktadır. En yüksek SP-B içeren toprak, ortalamanın üzerinde kil (\% 42) içermektedir. Spesifik adsorbe bor ile kil arasında önemli olmasa da pozitif bir ilişki olup, kil içeriğinin SP-B içeriğine olumlu etkisinin olduğu yargisına varılabilir. Nitekim Padbhushan ve Kumar (2017), kil içeriğinin SP-B içeriğini artırdığını rapor etmiştir. Spesifik adsorbe bor ile silt arasında ise önemli $(\mathrm{p}<0.05)$ negatif bir ilişki söz konusudur. Bu durum, aslında dolaylı bir ilişkidir. Kaba fraksiyonların fazla olması spesifik adsorpsiyon için gerekli şartların oluşmasını engellediği söylenebilir. Spesifik adsorpsiyon daha çok oksitlerin çözünme ve amorf yapıda tekrar çökelme sürecinde gerçekleşmektedir. Siltin fazla olması redoks potansiyelinin bu çözünmeleri oluşturabilecek kadar düşmesini engellediği düşünülmektedir.

\section{Oksitlere Bağlı Bor (OK-B)}

Oksitlere bağlı bor $0.15-0.43$ mgkg-1 arasinda değişmekte olup, ortalama $0.23 \mathrm{mg} \mathrm{kg}^{-1}$ ve toplam borun ortalama \% 0.84'ünü oluşturmaktadır (Çizelge 2). Topraklarda OK-B ile KÇ-B arasında istatistiksel olarak önemli $(\mathrm{p}<0.01)$ pozitif bir ilişki elde edilmiştir (Çizelge 3). Bu durum, topraklarda kolay çözünebilir bor fraksiyonunu OK-B'un olumlu yönde etkilediğini göstermektedir. Harmankaya ve Gezgin (2005) bor fraksiyonlarının belirlenmesi konusunda yaptıkları çalışmada, kolay çözünebilir B ile mangan oksitlere bağll $\mathrm{B}$, amorf $\mathrm{Fe}$ ve $\mathrm{Al}$ oksitlere bağll $\mathrm{B}$, kristalin $\mathrm{Fe}$ ve $\mathrm{Al}$ oksitlere bağlı bor arasında önemli pozitif ilişkinin olduğunu rapor etmiştir. Datta ve ark. (2002) oksitlere bağlı B'u ekstrakte etmek için kullanılan $\mathrm{NH}_{4}$-oksalat çözeltisinin kristalize ve kristalize olmayan $\mathrm{Fe}$ ve $\mathrm{Al}$ oksihidratları çözebildiğini, $\mathrm{NH}_{4}$ oksalat çözeltisinin ligant değişim yoluyla oksitler yüzeyinde tutulan $\mathrm{B}(\mathrm{OH})_{3}$ ve $\mathrm{B}(\mathrm{OH})_{4}^{-}$iyonlarını ektrakte edebildiğini bildirmiştir. Benzer şekilde OKB ile toprak organik madde içeriği arasında da önemli pozitif ilişki elde edilmiştir. Organik maddenin ayrışması ile ortaya çıkan organik bileşiklerin OKB'un ligant değişim yolu ile çözeltiye geçmesine katkıda bulunduğu yorumu yapılabilir. Aynı zamanda, topraklarda organik maddenin ayrışması sırasında yüksek oksijen ihtiyacı nedeniyle oksit bileşiklerinin indirgenmesine (Avnimelech ve ark., 2004; Liu ve ark., 2014) ve oksitler tarafindan adsorbe edilen borun serbestlenmesine neden olabilir. Ayrıca, oksitlere bağlı B'u ekstrakte etmek için kullanılan $\mathrm{NH}_{4}$ oksalat çözeltisi asidik karakterdedir. Asidik özellikte olan çözeltinin topraklarda kireç tarafindan adsorbe edilen B çözebilir ya da ekstrakte edebilir. Bu durum da OKB ile KÇ-B arasında önemli ilişkinin çıkmasına neden olabilir.

\section{Organik Maddeye Bağlı Bor (OM-B)}

Organik bileşiklere bağlı bor (OM-B) değerleri Çizelge 2 ' de görüldüğü gibi $0.13-0.34 \mathrm{mg} \mathrm{kg}^{-1}$ arasında değişmekte olup, ortalama ise $0.23 \mathrm{mg} \mathrm{kg}^{-1}$ dır. $\mathrm{Bu}$ 
fraksiyon, toplam borun ortalama \% 0.84 'ini oluşturmaktadır. Toprakların organik madde içeriği, topraklarda borun bitkiler tarafından alınabilirliğini ve tutulmasını önemli düzeyde etkilemektedir. Saltalı ve Akın (2011), Tokat Kazova topraklarında organik bileşiklere bağlı borun $0.11-2.66 \mathrm{mg} \mathrm{kg}^{-1}$ arasında değiştiğini ve ortalama $0.54 \mathrm{mg} \mathrm{kg} \mathrm{kg}^{-1}$ olduğunu saptamışlardır. Araştırma sonuçları Tokat Kazova topraklarına benzemektedir. Ancak, Konya ovası topraklarında organik maddeye bağlı borun, toplam bor içeriğinin \% 5,48'ini oluşturduğu bildirilmiştir (Harmankaya ve Gezgin, 2005). Bu çalışmada, ortama OM-B'un Konya Ovası topraklarına göre düşük olması, Konya Ovası topraklarının daha yüksek OM (ort. \% 2.1) ve toplam B (399 $\mathrm{mg} \mathrm{kg}^{-1}$ ) içermesine bağlanabilir.

Toprakların OM-B ile \% OM arasında istatistiksel olarak önemli $(\mathrm{p}<0.05)$ pozitif ilişki elde edilmiştir (Çizelge 3). Ayrıca, OM-B ile KÇ-B arasında da istatistiksel olarak önemli $(\mathrm{p}<0.01)$ pozitif ilişki elde edilmiştir. Hou ve ark. (1994), toprakların B fraksiyonu konusunda yaptıkları çalışmada, toprakların OM içeriği ile OM-B arasında önemli pozitif ilişkinin olduğunu rapor etmişlerdir. Bu durum, toprakların organik madde içeriğinin bölgede alınabilir B içeriğinin kontrolüne katkı yaptığını göstermektedir.

\section{Residüyal (Bakiye) Bor (RES-B)}

Araştırma topraklarının residüyal bor içerikleri, 19.5 ile $45.2 \mathrm{mg} \mathrm{kg}^{-1}$ arasında değişmekte olup, ortalama $26.1 \mathrm{mg} \mathrm{kg}^{-1}$ bulunmuştur (Çizelge 2). Residüyal bor fraksiyonu toprakların toplam bor içeriğinin ortalama \% 95.9 gibi yüksek bir kısmını oluşturmaktadır (Çizelge 2). Residüyal bor, bitkiler tarafından alınabilir formda değildir. RES-B topraklarda primer ve sekonder minerallerin yapisinda bulunmakta olup, kil minerallerindeki tabakalar arasında kuvvetli şekilde tutulmaktadır (Goldberg, 1997). Residüyal bor ile $\mathrm{pH}$ arasında önemli $(\mathrm{p}<0.01)$ negatif bir ilişki vardır (Çizelge 3). Bu durum toprak $\mathrm{pH}$ değerindeki değişime (azalma veya yükselme) bağlı olarak RES-B içeriğinin de dalgalı bir seyir izlediği şeklinde yorumlanabilir. Toprakların toplam bor içeriği ile RES-B arasında istatistiksel olarak önemli $(p<0.01)$ pozitif ilişki vardır ve bu durum RES-B'nin toplam borun çok yüksek bir kısmını oluşturmasının bir sonucudur (Çizelge2).

\section{SONUÇLAR ve ÖNERİLER}

Çalışma alanı topraklarının toplam B içeriği ortalama $27.20 \mathrm{mg} \mathrm{kg}^{-1}$ 'dır (Çizelge 2). Toplam B içeriğinin \% 95.88'ni RES-B oluşturmaktadır. Benzer şekilde toplam B'un \% 0.96'nı KÇ-B, \% 1.47'ni SPA-B, \% 0.84 'nü OK-B ve OM-B oluşturmaktadır. Araştırma sonuçlarına göre, toprak organik maddesi ile KÇ-B $(\mathrm{p}<0.01)$ ve OM-B $(\mathrm{p}<0.05)$ arasinda istatistiksel olarak önemli pozitif ilişki elde edilmiştir (Çizelge 3).
$\mathrm{Bu}$ durum, organik maddenin topraklarda KÇ-B miktarını olumlu yönde etkilediği şeklinde yorumlanabilir. $\mathrm{Bu}$ sonuçlara göre, antepfistığ yetiştirilen toprakların organik madde içeriğinin artırılması ile bor yarayışlılığının önemli ölçüde kontrol edilebileceği değerlendirilmektedir.

\section{Çıkar Çatışması Beyanı}

Makale yazarları aralarında herhangi bir çıkar çatışması olmadığını beyan ederler.

\section{Araştırmacıların Katkı Oranı Beyan Özeti}

Tüm yazarlar makaleye katkı sağlamış olduklarını beyan ederler.

\section{KAYNAKLAR}

Açar İ, Doran İ, Aslan N, Kalkancı ND 2016. Boron Affects the Yield and Quality of Noirrigated Pistachio (Pistacia vera L.) Trees. T J Agric Forest 40: 664-670.

Alpaslan M, Güneş A, İnal A 1998. Deneme Tekniği. Ankara Üni. Ziraat Fakültesi Yayınları No: 1501, Ankara, 56 sy.

Avnimelech Y, Ritvo G, Kochva M 2004. Evaluating the Active Redox and Organic Fractions in Pond Bottom Soils: EOM, Easily Oxidized Material. Aquaculture 233: 283-292.

Baydaa HA, Suad AS, Ibrahim BR 2019. Effect of Boron Supplement on Yield of Wheat Grown in Calcareous Soils of Different Textural Classes under Arid Conditions. J Agric Sci 11(1): 112-117.

Bayraklı F 1998. Toprak Kimyası. 19. Mayıs Ün. Zir. Fak. Ders Kitabı. No:26, Samsun, 90 sy.

Bouyoucus GJ 1952. A Recalibration of the Hydrometer for Making Mechanical Analysis of Soils. Agron J 43: 434-438.

Datta SP, Rattan RK, Suribabu K, Datta SC 2002. Fractionation and Colorimetric Determination of Boron in Soils. J Plant Nutr Soil Sci 165: 179-184.

Degryse F 2017. Boron Fertilizers: Use, Challenges and the Benefit of Slow-Release Sources - A Review. Boron 2 (3): $111-122$.

Elrashidi MA, O'Connor GA 1982. Boron Sorption and Desorption in Soils. Soil Sci Soc Am. J 46: 27-31.

Gürel S, Başar H, Keskin H, Dirim MS 2019. The Determination of Soil Boron Fractions, their Relationships to Soil Properties and the Availability to Olive ( Olea europea L.) Trees. Comm Soil Sci Plant Anal 50(3): 1-19.

Goldberg S 1997. Reaction of Boron with Soils. Plant Soil 193: 35-48.

Güçdemir İH 2006. Türkiye Gübre ve Gübreleme Rehberi, T.C. Tarım ve Köyişleri Bakanlığ 1 , TAGEM, Araştırma Enst. Müd. Yayınları. Genel yayın no: 231. Ankara.

Güneş A, Alpaslan M, İnal A 2000. Bitki Besleme ve Gübreleme. Ankara Üniversitesi Ziraat Fakültesi 
Yayınları, No:1514. Ankara, 461-487 sy.

Harmankaya M, Gezgin S 2005. Konya Ovası Topraklarında Bor Fraksiyonlarının Belirlenmesi. S.Ü. Zir Fak Derg 19 (36): 93-105.

Helmke PA, Sparks DL 1996. Lithium, Sodium, Potassium, Rubidium, and Calcium (Methods of Soil Analysis, Part 3, Chemical Methods, SSSA Book Series Number 5, SSSA, Madison USA: Sparks DL (Ed)) 551-574.

Hızalan E, Ünal H 1966. Topraklarda Önemli Kimyasal Analizler. A.Ü. Ziraat Fakültesi Yayınları. 278. Ankara, 5-7 sy.

Hou J, Evans L J, Spiers GA 1994. Boron Fractionation in Soils. Comm Soil Sci Plant Anal 25: 1841-1853.

Hou J, Evans L J, Spiers GA 1996. Chemical Fractionation of Soil Boron: I. Method Development. Can J Soil Sci 76: 485-491.

Karaduman A, Çimrin KM 2016. Gaziantep Yöresi Tarım Topraklarının Besin Elementi Durumları ve Bunların Bazı Toprak Özellikleri ile İlişkileri. KSÜ Doğa Bil Derg 19(2): 117-129.

Keren R, Gast RG 1983. pH-dependent Boron Adsorption by Montmorillonite Hidroxi-Aluminum Complexes. Soil Sci. Soc. Am. J 47(6): 1116-1121.

Lindsay W L, Norvell WA 1978. Development of a DTPA Soil Test for Zinc, İron, Manganese and Copper. Soil Sci Soc Am J 43: 421- 428.

Liu Y, Lou J, Li FB, Xu JM, Yu XS, Zhu LA, Wang F 2014. Evaluating Oxidation-Reduction Properties of Dissolved Organic Matter from Chinese Milk Vetch (Astragalus sinicus L.): A Comprehensive Multi-Parametric Study. Environ Technol 35 (1316): 1916-27.

Nelson DW, Sommers LE 1996. Total Carbon, Organic Carbon, and Organic Matter (Methods of Soil Analysis, Part 3, Chemical Methods, SSSA Book Series Number 5, SSSA, Madison USA: Sparks DL (Ed)) 961-1010.

Olsen SR, Cole CV, Watanabe FS, Dean LA 1954. Estimation of Available Phosphorus in Soils by Extraction with Sodium Bicarbonate. USDA Cric. 939. US Government Printing Office, Washington DC

Padbhushan R, Kumar D 2017. Fractions of Sol Boron: A Review. J Agric. Sci. 155: 1023-1032.

Richards L A 1954. Diagnosis and Improvement of Saline and Alkaline Soils, US Salinity Laboratory, USDA, Handbook, 60.

Saltalı K, Akın A 2011. Tokat Kazova Topraklarında Borun Kimyasal Fraksiyonları ve Bu Fraksiyonlar ile Toprak Özellikleri Arasındaki İlişkiler. Ege Ün. Zir. Fak Derg. Özel Sayı: 379-385.

SPSS 2013. IBM SPSS Statistics 21.0 for Windows. Armonk, NY.

Tessier, A., Campbell P.G.C. ve Bisson M., 1979. Sequential Extraction Procedure for the Speciatin of Particulate Trace Metals. Anal Chem 51: 844851. 